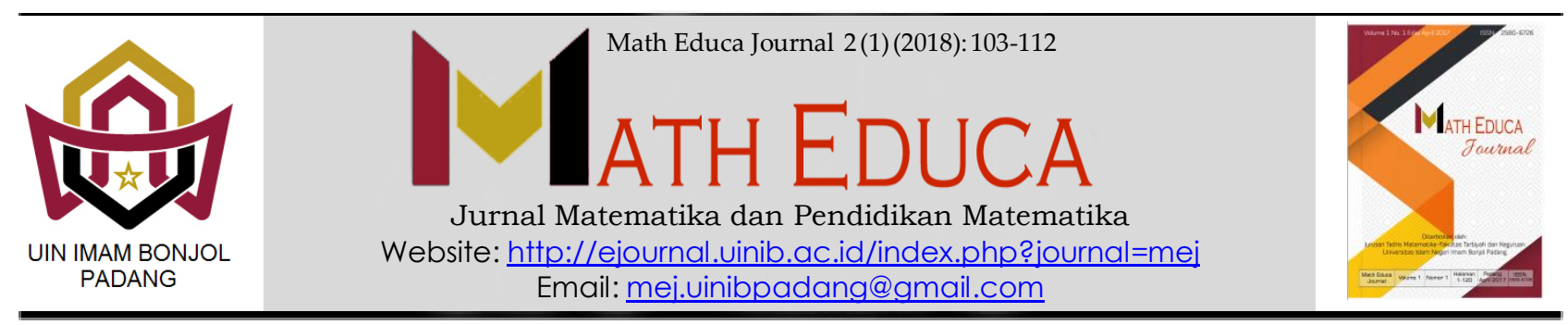

\title{
KEMAMPUAN PEMECAHAN MASALAH MATEMATIS PESERTA DIDIK YANG DIAJAR DENGAN MODEL PEMBELAJARAN MISSOURI MATHEMATICS PROJECT (MMP) DISERTAI STRATEGI THINK-TALK-WRITE (TTW) DI SMP NEGERI 2 LENGAYANG PESISIR SELATAN
}

\author{
Andi Susanto ${ }^{1}$ Rara Anggun Syaveta ${ }^{2}$ \\ ${ }^{1,2}$ Jurusan Tadris Matematika, Fakultas Tarbiyah dan Keguruan \\ e-mail: soulmath_andi@yahoo.co.id, syavetaanggun@gmail.com
}

Received: January 2018; Accepted: March 2018; Published: April 2018

\begin{abstract}
Abstrak
Penelitian ini dilatarbelakangi oleh rendahnya kemampuan pemecahan masalah matematis peserta didik kelas VIII SMPN 2 Lengayang. Tujuan dari penelitian ini adalah untuk mengkomparasikan kemampuan pemecahan masalah matematis peserta didik yang diajar dengan model Missouri Mathematics Project (MMP) disertai strategi Think-Talk-Write (TTW) dengan peserta didik yang menggunakan pendekatan saintifik. Penelitian ini merupakan penelitian quasy experiment. Populasi penelitian ini adalah seluruh peserta didik kelas VIII SMPN 2 Lengayang dan sampel dari penelitian ini adalah kelas VIII.A dan VIII.E.Berdasarkan hasil tes pada kelas eksperimen nilai rata-rata kemampuan pemecahan masalah matematis peserta didik yang diajar dengan model pembelajaran Missouri Mathematics Project (MMP) disertai strategi Think-Talk-Write (TTW) adalah 76 dan di kelas kontrol adalah 68. Uji hipotesis dengan uji-t satu arah, diketahui $\mathrm{t}_{\text {tabel }}=1,64$ dan $\mathrm{t}_{\text {hitung }}=2,23$ pada taraf kepercayaan 95\%, hal ini menunjukkan bahwa hipotesis diterima artinya kemampuan pemecahan masalah matematis peserta didik yang diajar dengan model pembelajaran Missouri Mathematics Project (MMP) disertai strategi Think-Talk-Write (TTW) lebih tinggi dari pada kemampuan pemecahan masalah matematis peserta didik yang diajar dengan pendekatan saintifik.
\end{abstract}

Kata kunci: Kemampuan Pemecahan Masalah Matematis, Model Pembelajaran Missouri Mathematics Project (MMP), Strategi Think-Talk-Write (TTW)

\begin{abstract}
This research is driven by the low level of problem solving ability of $8^{\text {th }}$ grade students of SMPN 2 Lengayang. This study aims to determine the problem-solving ability of mathematics students taught by matrix Missouri mathematics project with a strategy of Think-Talk-Write better than students who use the scientific approach. This research is a quasy experiment research. The population of this research is all students of class VIII SMPN 2 Lengayang, and sampel is this research class VIII.A and class VIII.E. Based on the results of this study obtained the average value of mathematical problem-solving skills of learners who were taught by MMP method with TTW strategy is 76 and the usual learning is 68. After hypothesis testing using t-test, known $t_{\text {table }}=$ 1,64 and $t_{\text {count }}=2,23$ with 95\% confidence level, this means that this indicates that the accepted hypothesis means the ability to solve mathematical problems of students with MMP with scientific approach.
\end{abstract}

Keyword: Mathematical Problem Solving Skills, Learning Model Type Missouri mathematics project (MMP), and strategy of Think-Talk-Write (TTW) 


\section{PENDAHULUAN}

Kemampuan pemecahan masalah merupakan salah satu kemampuan yang harus dimiliki peserta didik setelah belajar matematika. Salah satu tujuan pembelajaran matematika menurut Permendiknas Nomor 22 Depdiknas (2006) adalah agar peserta didik memiliki kemampuan memecahkan masalah yang meliputi kemampuan memahami masalah, merancang model matematika, menyelesaikan model, dan menafsirkan solusi yang diperoleh.

\section{Menurut Poerwadarminta}

kemampuan berarti kesanggupan, kecakapan, kekuatan. Pemecahan berarti perbuatan memecahkan, sedangkan masalah berarti soal atau sesuatu yang harus dipecahkan. Berdasarkan pengertian di atas, dapat disimpulkan bahwa kemampuan pemecahan masalah adalah suatu kesanggupan yang dimiliki peserta didik untuk memecahkan suatu soal.

Dalam proses pembelajaran maupun penyelesaian masalah matematika, peserta didik dimungkinkan memperoleh pengalaman menggunakan pengetahuan serta keterampilan yang sudah dimiliki. Melalui kegiatan pemecahan masalah, Aspek-aspek kemampuan matematika seperti penerapan aturan dalam masalah, penemuan pola, penggeneralisasian, komunikasi matematika dan lain-lain dapat dikembangkan dengan baik.

Kemampuan pemecahan masalah ini sangat penting dimiliki peserta didik agar peserta didik dapat menggunakannnya secara luwes, baik untuk belajar matematika peserta didik. Selanjutnya, untuk diterapkan pada ilmu lain, maupun untuk menghadapi masalah-masalah nyata yang dihadapinya. Salah satu sekolah yang kemampuan pemecahan masalah matematis peserta didiknya rendah adalah SMPN 2 Lengayang. Ini terlihat dari capaian hasil belajarnya.

Kurangnya kemampuan peserta didik dalam pemecahan masalah dipengaruhi oleh banyak faktor, salah satunya adalah kurangnya latihanlatihan soal yang diberikan oleh pendidik dan soal-soal yang diberikan hanya berupa soal-soal rutin. Upaya yang dilakukan untuk menciptakan pembelajaran yang dapat meningkatkan kemampuan pemecahan masalah peserta didik diantaranya dengan memilih dan menggunakan model pembelajaran yang relevan dan tepat.

Salah satu model pembelajaran yang dapat mengatasi permasalahan tersebut yaitu penggunaaan model Missouri Mathematics Project (MMP) disertai Strategi Think-Talk-Write (TTW). Menurut Convey dalam Krismanto (2003:11), Model pembelajaran ini merupakan suatu model pembelajaran matematika yang diterapkan di Missouri, suatu Negara bagian Amerika Serikat di bawah Departemen Missouri Pendidikan Dasar dan Menengah.

Model pembelajaran kooperatif tipe Missouri Mathematics Project (MMP) memiliki beberapa kelebihan, diataranya peserta didik diberikan banyak latihan-latihan soal sehingga peserta didik mudah terampil dengan beragam soal. Latihan-latihan soal diataranya lembar kerja peserta didik (mandiri), lembar kerja kelompok dan tugas rumah/PR. Selain itu ada materi yang bisa tersampaikan kepada peserta didik karena tidak terlalu memakan banyak waktu. Artinya, penggunaan waktu dapat diatur relatif ketat. 
Kemampuan Pemecahan Masalah... (Andi Susanto, Rara Anggun Syaveta) 105

Menurut Shadiq (2009:21), model Missouri Mathematics Project (MMP) memuat 5 langkah sebagai berikut:

a. Pendahuluan atau Review

1) Membahas PR.

2) Meninjau ulang pelajaran lalu yang berkait dengan materi baru.

3) Membangkitkan motivasi.

b. Pengembangan

1) Penyajian ide baru sebagai perluasan konsep matematika terdahulu.

2) Penjelasan, diskusi demonstrasi dengan contoh konkret yang sifatnya piktorial dan simbolik.

c. Latihan Dengan Bimbingan Pendidik

1) Peserta didik merespon soal.

2) Pendidik mengamati.

3) Belajar kooperatif.

d. Kerja Mandiri atau seat work

Peserta didik bekerja sendiri untuk latihan atau perluasan konsep pada langkah- 2 .

e. Penutup

1) Peserta didik membuat rangkuman pelajaran, membuat renungan tentang hal- hal baik yang sudah dilakukan serta hal-hal kurang baik yang harus dihilangkan.

2) Memberi tugas PR.

Kelebihan model pembelajaran MMP adalah peserta didik mudah terampil dengan beragam soal. Hal ini dikarenakan dalam model pembelajaran MMP peserta didik diberikan lembar tugas proyek yang berisi sederetan soal ataupun perintah untuk mengembangkan satu ide atau konsep matematis. Proyek ini dapat diselesaikan secara kelompok (pada langkah latihan terkontrol), secara individu (pada langkah seatwork) bahkan bersama-sama seluruh peserta didik dalam kelas (pada langkah pengembangan).

Melalui proyek ini peserta didik diharapkan dapat memiliki berbagai pengalaman dalam menyelesaikan permasalahan matematis yang nantinya dapat meningkatkan kemampuan pemecahan masalah matematis peserta didik. Hal ini sesuai dengan pernyataan Suherman dkk (2003: 93) yang menyatakan bahwa untuk memperoleh kemampuan dalam pemecahan masalah seseorang (dalam hal ini peserta didik) harus memiliki banyak pengalaman dalam memecahkan berbagai masalah atau soal.

Waktu pemahaman peserta didik dalam aspek kemampuan pemecahan masalah harus diperhatikan. Diperlukan strategi yang sesuai dan tepat untuk membantu peserta didik mempercepat memahami suatu permasalahan. Strategi merupakan trik atau tips agar dapat mengatasi suatu masalah. Salah satu strategi pembelajaran yang dapat mengatasi permasalahan tersebut adalah Strategi Think-Talk-Write.

Strategi Think-Talk-Write merupakan rangkaian pembelajaran yang terdiri dari tiga tahap yaitu : (1) Think, dalam tahap ini peserta didik secara individu membaca teks bacaan pada lembar kerja peserta didik (LKP). Peserta didik memikirkan kemungkinan jawaban (strategi penyelesaian), menandai konsep yang dianggap penting, atau yang tidak dipahami, hasilnya ditulis dalam catatan kecil, (2) talk, dalam tahap ini peserta didik mengkomunikasikan hasil kegiatan membacanya pada tahap think melalui diskusi (dalam kelompok yang terdiri dari 4-6 orang) sampai mendapatkan solusi, dan (3) write, dalam tahap ini peserta didik menulis kembali hasil diskusi pada lembar kegiatan peserta didik (LKP) berupa landasan, keterkaitan, strategi, serta solusi dari soal.

Martinis Yamin dan Bansu I. Ansari (2008: 84) menyatakan Think-Talk-Write (TTW) merupakan strategi pembelajaran yang dikembangkan oleh Huinker dan Laughlin. Strategi pembelajaran TTW ini didasarkan pada 
pemahaman bahwa belajar adalah sebuah perilaku sosial. Strategi TTW pada dasarnya dibangun melalui berpikir, berbicara, dan menulis Strategi pembelajaran ini merupakan strategi yang dapat melatih kemampuan berpikir dan berbicara peserta didik.

Untuk meminimalisir kekurangan model Missouri Mathematics Project (MMP) dan strategi Think-Talk-Write (TTW) maka dilakukan pengkombinasian, dimana langkah-langkahnya menurut Asep Frey Faizan dalam Krismanto (2003:15) antara lain :

\section{a. Langkah I (Review)}

Pada tahap review ini, yaitu tahap dalam model MMP, adalah meninjau ulang materi pembelajaran yang lalu.

b. Langkah II (Pengembangan)

Pada tahap kedua model MMP ini yaitu tahap pengembangan adalah melakukan kegiatan berupa penyajian ide-ide baru dan perluasannya, diskusi, kemudian menyertakan demonstrasi dengan contoh konkret.

c. Langkah III: (Latihan Terkontrol dengan Strategi Thik-Talk-Write)

Langkah ketiga pada model MMP yaitu latihan terkontrol. Peserta didik mengerjakan Lembar Kerja Proyek dikombinasikan dengan strategi Think-TalkWrite.

d. Langkah IV (Seatwork/Kerja Mandiri) Pada langkah keempat model MMP ini peserta didik secara individu diberikan beberapa soal atau pertanyaan sebagai latihan atas perluasan konsep materi.

e. Langkah V : penutup

Pada langkah ini, peserta didik beserta pendidik bersama-sama membuat kesimpulan (rangkuman) atas materi pembelajaran yang telah didapatkan.

Dari penggabungan model Missouri Mathematics Project (MMP) dan strategi ThinkTalk-Write (TTW) ini, dapat meningkatkan kemampuan pemecahan masalah matematis peserta didik dalam proses pembelajaran.
Rumusan masalah penelitian ini "Apakah kemampuan pemecahan masalah matematis peserta didik yang diajar dengan model missouri mathematics project (MMP) dengan strategi Think-talk-write (TTW) lebih tinggi dari pada kemampuan pemecahan masalah matematis peserta didik yang menggunakan pendekatan saintifik?" tujuan membandingkan kemampuan pemecahan masalah matematis peserta didik yang diajar dengan model missouri mathematics project (MMP) dengan strategi Think-talk-write (TTW) lebih tinggi dari pada kemampuan pemecahan masalah matematis peserta didik yang menggunakan pendekatan saintifik.

Penelitian serupa sudah dilakukan oleh Hidayah Ansori, Irsanti Aulia (2015). Perbedaan penelitian ini dengan sebelumnya adalah penelitian ini disertai strategi Think-Talk-Write (TTW) sedangkan penelitian sebelumnya hanya menggunakan model Missouri Mathematics Project (MMP) saja. Dan penelitian juga dilakukan oleh Wirdhatul Usnah (2014). Perbedaan penelitian ini dengan sebelumnya adalah penelitian ini melihat kemampuan pemecahan masalah matematis peserta didik serta diterapkan dalam kurikulum 2013 sedangkan penelitian sebelumnya melihat hasil belajar matematika dan menerapkan kurikulum KTSP, serta hipotesis dalam penelitian ini adalah "Kemampuan Pemecahan Masalah Matematis peserta didik yang diajar dengan model pembelajaran Missouri Mathematics Project (MMP) disertai strategi Think-Talk-Write (TTW) lebih tinggi dari pada kemampuan Pemecahan Masalah Matematis peserta didik dengan 
menggunakan pembelajaran biasa di kelas VIII SMP N 2 Lengayang.”

\section{METODE PENELITIAN}

\section{Jenis Penelitian}

Jenis penelitian ini adalah penelitian eksperimen semu (quasi experimental research). Sedangkan rancangan penelitian yang digunakan adalah Randomized Sumber Control Group Only Design.

Tabel 1. Randomized Control Group Only Design

\begin{tabular}{lcc}
\hline \multicolumn{1}{c}{ Kelas } & Perlakuan & Tes akhir \\
\hline Kelas Eksperimen & $\mathrm{X}$ & $\mathrm{T}$ \\
Kelas Kontrol & - & $\mathrm{T}$ \\
\hline
\end{tabular}

Sumber : Sumadi Suryabrata (2004:104)

Keterangan :

$\mathrm{X}=$ Perlakuan yang diberikan kepada kelas eksperimen yaitu model pembelajaran Missouri mathematics project (MMP) dengan strategi Think-talk-write (TTW).

$\mathrm{T}=$ Kemampuan pemecahan masalah.

\section{Waktu dan Tempat Penelitian}

Waktu penelitian ini dimulai tanggal 04 September - 24 September 2017 di SMPN 2 Lengayang Kabupaten Pesisir Selatan tahun ajaran 2017/2018 Semester ganjil.

\section{Data, Intrumen, dan Teknik Pengumpulan Data}

Populasi penelitian ini adalah seluruh peserta didik kelas VIII SMPN 2 Lengayang. Sampel dari penelitian ini adalah kelas VIII.A, VIII.E. Penelitian ini ada tiga prosedur penelitian yang dilakukan 1) tahap persiapan 2) tahap pelaksanaan 3) tahap penyelesaian.

\section{1) Jenis Data}

Jenis data yang digunakan dalam penelitian ini terdiri atas data primer dan data sekunder yaitu : a. Data primer pada penelitian ini adalah data yang diambil dari nilai tes kemampuan pemecahan masalah matematis dengan menerapkan model pembelajaran Missouri mathematics project (MMP) dengan strategi Thinktalk-write (TTW) di Kelas eksperimen.

b. Data sekunder pada penelitian ini adalah seluruh nilai ulangan harian I matematika semester I peserta didik kelas VIII SMPN 2 Lengayang tahun ajaran 2017/2018 dan seluruh jumlah peserta didik yang menjadi sampel dalam penelitian ini.

2) Sumber Data

Data primer bersumber dari peserta didik kelas VIII SMPN 2 Lengayang tahun ajaran 2017/2018 semester I yang menjadi sampel dalam penelitian ini dan data sekunder yaitu data yang bersumber dari tata usaha dan pendidik bidang studi matematika.

3) Instrumen Penelitian

Instrumen penelitian yang digunakan berupa tes hasil belajar yang berfungsi untuk mengukur tingkat kemampuan pemecahan masalah matematis peserta didik.

4) Teknik pengumpulan data

Teknik Pengumpulan data pada penelitian ini adalah hasil tes kemampuan pemecahan masalah matematis yang menggunakan tes essay.

\section{Teknik Analisis Data}

Teknik analisis data pada penelitian ini adalah uji-t. Sebelum melakukan uji -t terlebih dahulu dilakukan uji normalitas dan uji homogenitas terhadap kelas sampel. 
1. Uji normalitas

Uji normalitas yang digunakan dalam penelitian ini adalah uji Liliefors.

2. Uji Homogenitas Variansi

Uji homogenitas pada peneltian ini menggunkan uji Bartlett.

\section{Uji Hipotesis}

Uji hipotesis yang digunakan dalam penelitian ini dalah uji-t dengan hipotesis stasitik :

Kelas eksperimen dan kontrol

$$
\begin{aligned}
& H_{0}: \mu_{1} \leq \mu_{2} \\
& H_{1}: \mu_{1}>\mu_{2}
\end{aligned}
$$

Dengan :

$\mu_{1}=$ Rata-rata kemampuan pemecahan masalah matematis peserta didik pada kelas eksperimen I (model pembelajaran Missouri mathematics project (MMP) disertai strategi Think-talk-write (TTW).

$\mu_{2}=$ Rata-rata kemampuan pemecahan masalah matematis peserta didik pada kelas Kontrol.

Rumus untuk uji hipotesis yang digunakan dalam penelitian ini, Sudjana (2005:243) adalah sebagai berikut :

$$
t=\frac{\overline{x_{1}}-\overline{x_{2}}}{s \sqrt{\frac{1}{n_{1}}+\frac{1}{n_{2}}}}
$$

dengan: $\quad S=\frac{\left(n_{1}-1\right) s_{1}^{2}+\left(n_{2}-1\right) s_{2}^{2}}{n_{1}+n_{2}-2}$

Keterangan :

$\overline{x_{1}}=$ Skor rata-rata nilai kelas eksperimen

$\overline{x_{2}}=$ Skor rata-rata nilai kelas kontrol

$S_{1}^{2}=$ Variansi terbesar

$S_{2}^{2}=$ Variansi terkecil

$S^{2}=$ Variansi dari kedua sampel

$n_{1}=$ Jumlah peserta didik kelas eksperimen

$n_{2}=$ Jumlah peserta didik kelas kontrol

$S=$ Standar baku gabungan

$S_{1}=$ Standar baku kelas eksperimen

$S_{2}=$ Standar baku kelas kontrol
Kriteria Pengujian pada taraf kepercayaan 95\% adalah jika $t_{\text {hitung }}>t_{\text {tabel }}$, maka $H_{0}$ ditolak dan $H_{1}$ diterima.

\section{HASIL PENELITIAN DAN PEMBAHASAN}

Berdasarkan penelitian yang telah dilaksanakan maka diperoleh data hasil kemampuan pemecahan masalah matematis peserta didik, dapat dilihat pada tabel 2.

\section{Tabel 2. Deskripsi Data Kemampuan Pemecahan Masalah Matematis}

\begin{tabular}{cccccc}
\hline Kelas & N & Min & Max Mean & S \\
\hline Eksperimen & 22 & 55 & 94 & 76 & 10,60 \\
Kontrol & 22 & 46 & 86 & 68 & 12,90
\end{tabular}

Keterangan :

Max : Nilai tertinggi

Min : Nilai terendah

Mean : Rata-rata

S : Standar deviasi

Berdasarkan Tabel 2 dapat dilihat hasil

kemampuan pemecahan masalah matematis peserta didik kelas eksperimen yang diajar dengan model pembelajaran Missouri Mathematics Project (MMP) disertai Strategi Think-Talk-Write (TTW) memiliki rata-rata 76, standar deviasi 10.60 sedangkan pada kelas kontrol tes akhir hasil kemampuan pemecahan masalah matematis peserta didik memiliki ratarata 68, standar deviasi 12.90. Dari nilai ratarata kemampuan pemecahan masalah matematis kedua sampel, terlihat bahwa kelas eksperimen memiliki kemampuan pemecahan masalah matematis yang lebih baik dibanding kelas kontrol. Nilai maksimum hasil tes akhir kelas eksperimen adalah 94 lebih tinggi dari nilai maksimum hasil tes kelas kontrol yaitu 86 dan 
nilai minimum kelas eksperimen adalah 55 lebih tinggi dari kelas kontrol yaitu 46.

Hal ini berarti bahwa rata-rata kemampuan pemecahan masalah matematis peserta didik pada kelas eksperimen lebih baik dibandingkan kelas kontrol. Standar deviasi kelas eksperimen lebih kecil dari dtandar deviasi kelas kontrol. Hal ini mengidentifikasi bahwa nilai data terkonsentrasi di sekitar nilai pusatnya artinya nilai data kemampuan pemecahan masalah matematis peserta didik pada kelas eksperimen mendekati nilai rata-ratanya bila dibandingkan kelas kontrol.

Berdasarkan Kriteria Ketuntasan Minimal (KKM) yang telah ditetapkan SMPN 2 Lengayang yaitu 75 pada pelajaran matematika, dari hasil tes kemampuan pemecahan masalah matematis peserta didik pada kelas eksperimen diketahui nilai peserta didik yang mencapai KKM sebanyak 13 peserta didik, sedangkan pada kelas kontrol sebanyak 9 peserta didik sehingga persentase ketuntasan masing-masing kelas eksperimen dan kontrol berturut-turut adalah $59,09 \%$ dan 40,91\%, artinya hasil tes kemampuan pemecahan masalah matematis peserta didik kelas eksperimen lebih tinggi dari kelas kontrol.

Tabel 3. Kemampuan Pemecahan Masalah Matematis Berdasarkan Indikator :

\begin{tabular}{cccc}
\hline No & $\begin{array}{c}\text { Indikator } \\
\text { Pemecahan } \\
\text { Masalah }\end{array}$ & Eksperimen & Kontrol \\
\hline 1 Memahami & 91 & 84 \\
& $\begin{array}{l}\text { Masalah } \\
\text { Merencanakan } \\
\text { Penyelesaian } \\
\text { Menyelesaikan } \\
\text { Masalah }\end{array}$ & 68 & 72 \\
4 Pemeriksaan \\
Kembali
\end{tabular}

Dilihat dari Tabel 3 terlihat bahwa nilai rata-rata hasil tes akhir kemampuan pemecahan masalah matematis pada setiap indikator yang lebih tinggi diperoleh oleh kelas eksperimen dari pada kelas kontrol. Hal ini terjadi karena pada kelas eksperimen peserta didik menyelesaikan soal dengan indikator pemecahan masalah yaitu memahami masalah, merencanakan penyelesaian, menyelesaikan masalah, dan pemeriksaan kembali.

Berdasarkan indikator dalam pemecahan masalah, pada indikator memahami masalah pada kelas eksperimen mendapat nilai rata-rata yaitu 91 sedangkan pada kelas kontrol mendapat nilai rata-rata 84. Hal ini dikarenakan pada kelas eksperimen pada langkah pendahuluan pendidik memberikan tinjauan ulang materi pembelajaran yang lalu terutama yang berkaitan dengan materi yang akan dipelajari, sehingga pesertra didik benar-benar paham dan mengerti dengan materi yang akan dipelajari. Hal ini juga didukung dengan strategi Think-Talk-Write dimana peserta didik diminta berfikir tentang masalah pada soal kemudian peserta didik mengomunikasikan halhal yang telah diamatinya serta peserta didik diminta menuliskan hasil temuannya dalam catatannya masing-masing. Peserta didik juga ditekankan bahwa dalam menyelesaikan suatu soal peserta didik harus dapat memahami masalah yang diminta oleh soal tersebut. Peserta didik harus dapat mengidentifikasi apa yang diketahui dan ditanya pada soal tersebut.

Sedangkan kelas kontrol yang pada langkah pendahuluannya hanya diberikan apersepsi sehingga peserta didik kadang kurang mengerti terhadap materi yang akan dipelajari. Pada kelas kontrol juga tidak begitu menekankan 
pada peserta didiknya bahwa suatu soal harus dipahami pemasalahannya terlebih dahulu sehingga pada langkah memahami masalah kelas kontrol hanya mendapat nilai rata-rata yaitu 84 .

Pada indikator kedua yaitu merencanakan penyelesaian kelas eksperimen mendapat nilai rata-rata yaitu 68 sedangkan pada kelas kontrol mendapat nilai rata-rata 63 . Hal ini dikarenakan pada langkah merencanakan masalah kelas eksperimen peserta didik melakukan kegiatan pengembangan yaitu melakukan kegiatan berupa penyajian ide-ide baru dan perluasannya, diskusi kemudian menyertakan demonstrasi dengan contoh konkret yang berhubungan dengan materi yang sedang dipelajari.

Sedangkan pada kelas kontrol peserta didik hanya diberikan contoh soal yang berhubungan dengan materi. Peserta didik sering kurang mengerti terhadap contoh soal yang diberikan namun peserta didik malu untuk bertanya kepada pendidik sehingga kegiatan ini tidak mengahasilkan hasil yang maksimal.

Perbedaan nilai rata-rata yang diperoleh oleh kelas eksperimen dan kontrol pada langkah merencanakan penyelesaian ini tidak berbeda jauh dan terbilang cukup rendah. Hal ini dikarenakan pada langkah merencanakan masalah ini peserta didik di kelas eksperimen kurang memperhatikan dan menganggap bahwa suatu permasalahan atau soal tidak perlu direncanakan penyelesaiannya sehingga peserta didik cenderung lupa dengan rumus atau konsep yang harus dipahami dan diminta oleh suatu soal begitu juga pada kelas kontrol.

Pada indikator pemecahan masalah yang ketiga yaitu menyelesaikan masalah kelas eksperimen mendapat nilai rata-rata yaitu 84 dan pada kelas kontrol mendapat nilai rata-rata yaitu 72. Hal ini dikarenakan pada kelas eksperimen peserta didik telah terbiasa dalam memilih strategi pemecahan masalah. Hal ini juga disebabkan pada kelas eksperimen peserta didik melakukan latihan terkontrol dengan bimbingan pendidik berupa mengerjakan lembar kerja proyek dan lembar kerja mandiri.

Pada lembar kerja proyek peserta didik dapat bekerja sama dengan kelompoknya masingmasing. Jika peserta didik mengalami kesulitan dalam memecahkan suatu soal peserta didik dapat bertanya kepada pendidik sehingga tidak terjadi miskonsepsi dalam pembelajaran. Pada pengerjaan latihan terkontrol ini juga dikombinasikan dengan strategi Think-TalkWrite. Sedangkan pada latihan mandiri peserta didik secara individu diberikan soal sebagai latihan atas perluasan konsep materi yang telah dipelajari pada langkah pengembangan dan menguji kemampuan masing-masing peserta didik terhadap materi yang telah dipelajari. Dengan adanya latihan terkontrol dan latihan mandiri peserta didik lebih terbiasa menyelesaikan soal-soal dengan langkah-langkah pemecahan masalah serta wawasan yang dimiliki oleh peserta didik lebih banyak seiring seringnya mengerjakan latihan.

Sedangkan pada kelas Kontrol peserta didik hanya diberikan beberapa contoh soal yang rutin dan tidak bervariasi sehingga peserta didik kurang memiliki pengetahuan tentang soal-soal lain selain soal rutin. Pada kelas kontrol juga kebanyakan peserta didik lebih mengharapkan bantuan dari pendidik sehingga banyak peserta 
didik yang hanya diam dan menanti jawaban baik itu dari peserta didik lain maupun dari pendidik.

Pada indikator pemecahan masalah yang terakhir yaitu pemeriksaan kembali kelas eksperimen mendapat nilai rata-rata yaitu 61 dan kelas kontrol mendapat nilai rata-rata yaitu 53. Hal ini dikarenakan pada kelas eksperimen peserta didik terbiasa mengerjakan soal dengan langkah-langkah pemecahan masalah, dimana setelah menyelesaikan suatu soal peserta didik harus memeriksa kembali hasil temuannya sehingga peserta didik dituntut teliti dalam menyelesaikan soal. Hal ini dapat mengurangi tingkat kesalahan yang sering dilakukan oleh peserta didik. Sedangkan pada kelas kontrol peserta didik terbiasa bahwa suatu soal telah selesai jika telah mendapat hasil dari permasalahannya tanpa mengetahui hasil yang peserta didik dapatkan tersebut benar atau salah. Hal ini lah yang sering menjadikan peserta didik mendapat nilai yang rendah, karena peserta didik tidak melalkukan pemeriksaan ulang terhadap hasil yang telah didapatnya tersebut. Dari keempat indikator pemecahan masalah, indikator ini merupakan indikator yang mendapat nilai paling rendah karena peserta didik menganggap bahwa dalam menyelesaikan suatu soal kegiatan pemeriksaan kembali sering dilupakan dan diabaikan. Namun kelas eksperimen mendapat nilai rata-rata yang lebih tinggi dari pada kelas kontrol.

Pembelajaran dengan model Missouri Mathematics Project (MMP) Disertai strategi Think-Talk-Write (TTW) ini dapat melatih kemampuan pemecahan masalah peserta didik karena diberikan lebih banyak soal-soal latihan sehingga peserta didik dapat menyelesaikan soal- soal aplikasi maupun kompleks. Melalui model ini juga peserta didik dilatih mengerjakan soal dengan langkah-langkah pemecahan masalah yaitu memahami masalah, merencanakan masalah, menyelesaikan masalah, dan pemeriksaan kembali.

Pada awal pendidik mulai menerapkan menyelesaikan soal dengan langkah pemecahan masalah peserta didik banyak tidak paham, sehingga peserta didik menyelesaikan soal langsung pada proses penyelesaiannya saja tanpa melalui langkah memahami masalah dan merencanakan masalah. Sedangkan setelah selesai menyelesaikan masalah, peserta didik tidak melakukan pemeriksaan kembali pada hasil temuannya. Seiring berjalannya waktu peserta didik sudah mulai terbiasa dengan langkah menyelesaikan soal dengan pemecahan masalah.

Pada Dilihat dari hasil tes akhir kemampuan pemecahan masalah matematis, diperoleh bahwa nilai rata-rata kelas eksperimen lebih tinggi dari pada kelas kontrol. Hal ini dikarenakan pada kelas eksperimen diberikan perlakuan berupa pembelajaran dengan model pembelajaran Missouri Mathematics Project (MMP) disertai strategi Think-Talk-Write (TTW) sedangkan pada kelas kontrol menggunakan pembelajaran biasa yang kegiatan pembelajarannya lebih sering berpusat pada pendidik. Meskipun hasil yang didapat peserta didik pada kelas eksperimen lebih baik dari pada kelas kontrol namun pendidik merasa hasil yang didapat masih kurang dan masih bisa dimaksimalkan. Hal ini dikarenakan masih ada peserta didik yang pada tahap pelaksanaan pembelajaran sering kurang fokus, mengandalkan peserta didik lain dalam mengerjakan kerja 
proyek, dan ceroboh dalam mengerjakan soal. Hal ini berdampak pada hasil uji tes akhir yang didapat peserta didik tidak maksimal.

Berdasarkan tes akhir yang dilakukan pada kelas eksperimen dan kelas kontrol terlihat bahwa terdapat pembedaan kemampuan pemecahan masalah matematis pada kelas eksperimen dan kelas kontrol. Ini menunjukkan bahwa penggunaan model Missouri Mathematics Project (MMP) Disertai Strategi Think-TalkWrite (TTW) dapat meningkatkan kemampuan pemecahan masalah matematis peserta didik.

\section{SIMPULAN DAN SARAN}

\section{Simpulan}

Kemampuan pemecahan masalah matematis peserta didik yang diajar dengan model pembelajaran Missouri Mathematics Project (MMP) disertai strategi Think-Talk-Write (TTW) lebih baik dari pada kemampuan pemecahan masalah matematis peserta didik yang menggunakan pembelajaran biasa.

\section{Saran}

Diharapkan kepada peneliti selanjutnya agar dapat melanjutkan dan mengembangkan penelitian ini pada pokok bahasan lain, salah satu kemampuan matematika selain kemampuan pemecahan masalah dan pengkombinasian model pembelajaran Missouri Mathematics Project (MMP) dengan strategi lain selain strategi ThinkTalk-Write (TTW).

\section{REFERENSI}

Ansori Hidayah, Irsanti Aulia. 2015. Penerapan model pembelajaran Missouri Mathematics Project (MMP) terhadap Kemampuan Pemecahan Masalah Peserta didik di SMP. Jurnal. Program Sarjana FKIP Universitas Lambung Mangkurat.

Depdiknas. 2006. Permendiknas Nomor 22 Tahun 2006 tentang standar isi. Jakarta: Depdiknas.

Huinker, D dan Laughlin. 1996. Communication In Mathematics, K-12 And Beyond. USA: NCTM.

Krismanto, Al. 2003. Beberapa teknik, model dan strategi dalam pembelajaran matematika. Yogyakarta : Depdiknas Dirjen Pendidikan Dasar dan Menengah.

Martinis Yamin dan Bansu I. Ansari. 2008. Taktik mengembangkan kemampuan Individual Siswa. Jakarta : Gaung Persada Press.

Poerwadarminta. 1995. Kamus Umum Bahasa Indonesia. Jakarta: Balai Pustaka.

Shadiq, Fajar. 2009. Model-Model Pembelajaran matematika SMP. D.I. Yogyakarta : Depdiknas.

Suherman, Erman dkk. 2003. Strategi Pembelajaran Matematika Kontemporer. Jakarta: FMIPA UP.

Sudjana, Nana. 2005. Metode Statistika.. Bandung: Tarsito.

Suryabrata, Sumadi. 2004 .Metodologi Penelitian. Jakarta: Raja Grafindo Persada.

Usnah, Wirdhatul. 2014. Penerapan Model Missouri Mathematics Project (MMP) Melalui Strategi Snowball Throwing Dalam Pembelajaran Matematika Peserta Didik Kelas VIII SMPN 6 Koto Singkarak. Skripsi. Padang: UIN IMAM BONJOL. 